\title{
Recent progress of seismic observation networks in Japan -Hi-net, F-net, K-NET and KiK-net-
}

\author{
Yoshimitsu Okada ${ }^{1}$, Keiji Kasahara ${ }^{1}$, Sadaki Hori ${ }^{1}$, Kazushige Obara ${ }^{1}$, Shoji Sekiguchi ${ }^{1}$, Hiroyuki Fujiwara ${ }^{1}$, and Akira Yamamoto $^{2}$ \\ ${ }^{1}$ National Research Institute for Earth Science and Disaster Prevention, Tsukuba, Ibaraki 305-0006, Japan \\ ${ }^{2}$ Association for the Development of Earthquake Prediction, Tokyo 101-0064, Japan
}

(Received October 18, 2003; Revised July 26, 2004; Accepted July 28, 2004)

\begin{abstract}
After the disastrous 1995 Kobe earthquake, a new national project has started to drastically improve seismic observation system in Japan. A large number of strong-motion, high-sensitivity, and broadband seismographs were installed to construct dense and uniform networks covering the whole of Japan. The new high-sensitivity seismograph network consisting of 696 stations is called Hi-net, while the broadband seismograph network consisting of 71 stations is called F-net. At most of Hi-net stations strong-motion seismographs are also equipped both at depth and the ground surface. The network of these 659 stations with an uphole/downhole pair of strong-motion seismographs is called KiK-net, while another network consisting of 1034 strong-motion seismographs installed at the ground surface is called K-NET. Here, all the station numbers are as of April 2003. High-sensitivity data from Hi-net and pre-existing seismic networks operated by various institutions have been transmitted to and processed by the Japan Meteorological Agency since October 1997 to monitor the seismic activity in and around Japan. The same data are shared to university group in real time using satellite communication for their research work. The data are also archived at the National Research Institute for Earth Science and Disaster Prevention and stored in their database system for public use under a fully open policy.
\end{abstract}

Key words: Seismic network, Hi-net, F-net, K-NET, KiK-net.

\section{Introduction}

Following the occurrence of disastrous Hyogoken-nanbu (Kobe) earthquake of January 17, 1995, the Japanese government established the 'Headquarter for Earthquake Research Promotion' (HERP) on July 18, 1995 and set up the 'Fundamental Survey and Observation Plan for Earthquake Research' on August 29, 1997. In short, this plan is hereafter referred to the KIBAN project, where KIBAN is a Japanese word to mean fundamental or infrastructure.

The goals of this plan are to evaluate long-term possibility of earthquake occurrence through understanding of the earthquake phenomena and to construct a nation-wide probable shaking map through understanding of the generation mechanism of strong motions. The followings were selected as the core items of the KIBAN project.

(1) Seismic observation

(a) High-sensitivity seismic observation (microearthquake observation)

(b) Broadband seismic observation

(2) Observation of strong motion

(3) Observation of crustal movement (continuous GPS observation)

(4) Survey of active faults in inland and coastal regions

In this paper, we report the state of the art regarding to items (1) and (2). The KIBAN project recommended construction of seismic observation networks covering the whole

Copy right (c) The Society of Geomagnetism and Earth, Planetary and Space Sciences (SGEPSS); The Seismological Society of Japan; The Volcanological Society of Japan; The Geodetic Society of Japan; The Japanese Society for Planetary Sciences; TERRAPUB. of Japan with a station spacing of about $20 \mathrm{~km}(100 \mathrm{~km}$ for broadband observation) utilizing the existing stations as much as possible. It means approximately 1000 stations are needed for high-sensitivity and strong-motion networks and 100 stations for broadband network. The KIBAN project also requires that these observations should be stably and continuously maintained for at least several tens of years and the obtained data must be widely and quickly distributed to the public under a fully open policy.

As to the item (3), a nation-wide continuous GPS observation network was constructed by the Geographical Survey Institute. The network is called GEONET and consists of nearly 1200 stations covering the whole of Japan (Hatanaka et al., 2003; Sagiya, 2004).

\section{Overview of Seismic Observation Networks in Japan}

\subsection{Before Kobe earthquake}

At the time of 1995 Kobe earthquake, several highsensitivity seismic observation networks had been operated in Japan by individual organizations. The Japan Meteorological Agency (JMA) operated a nation-wide network consisting of 188 stations to detect small to large earthquakes occurring in and around Japan. University group (UNIV) maintained their local networks for microearthquake observation as well as dense arrays at specific sites of research interests. Total number of the seismic stations operated by them was 274. The National Research Institute for Earth Science and Disaster Prevention (NIED) operated a network consisting of 89 highly sensitive stations in the Kanto-Tokai region, cen- 


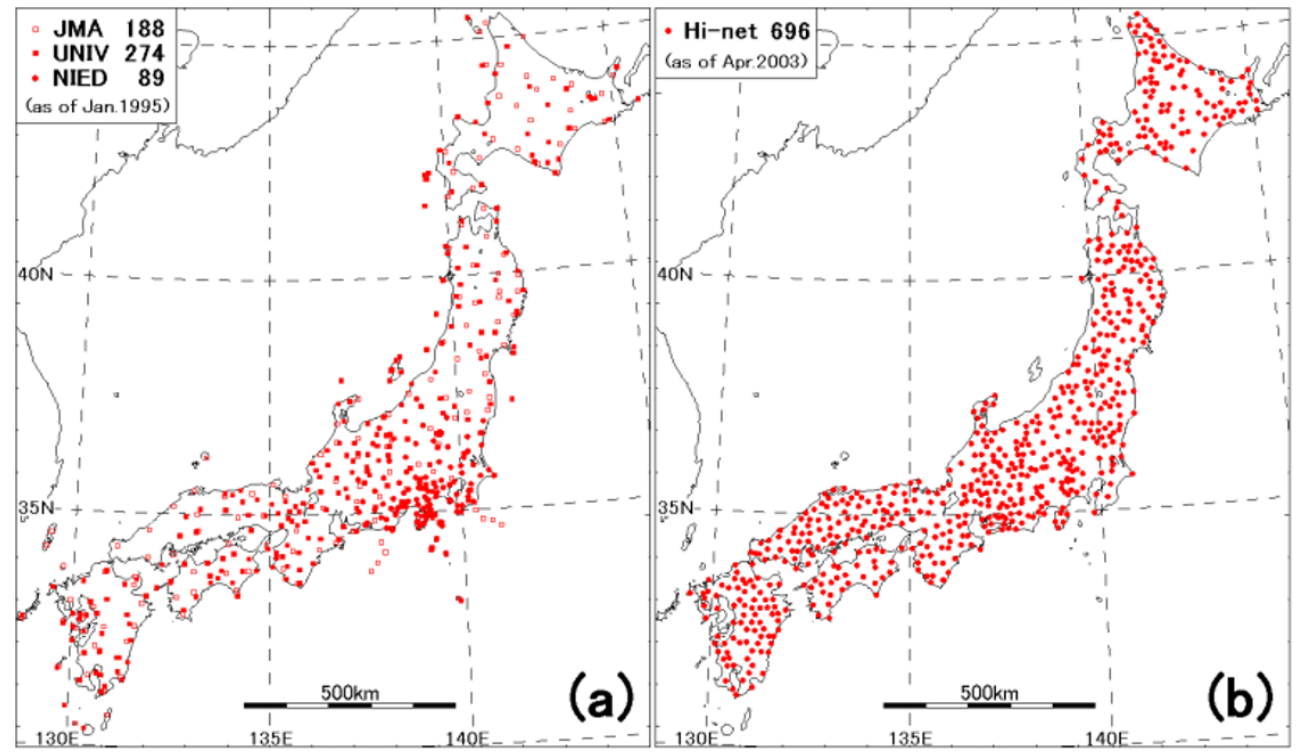

Fig. 1. Distribution of high sensitivity seismic stations in Japan (a) at the time of 1995 Kobe earthquake and (b) newly added Hi-net stations as of April 2003 (JMA: Japan Meteorological Agency, UNIV: University, NIED: National Research Institute for Earth Science and Disaster Prevention).

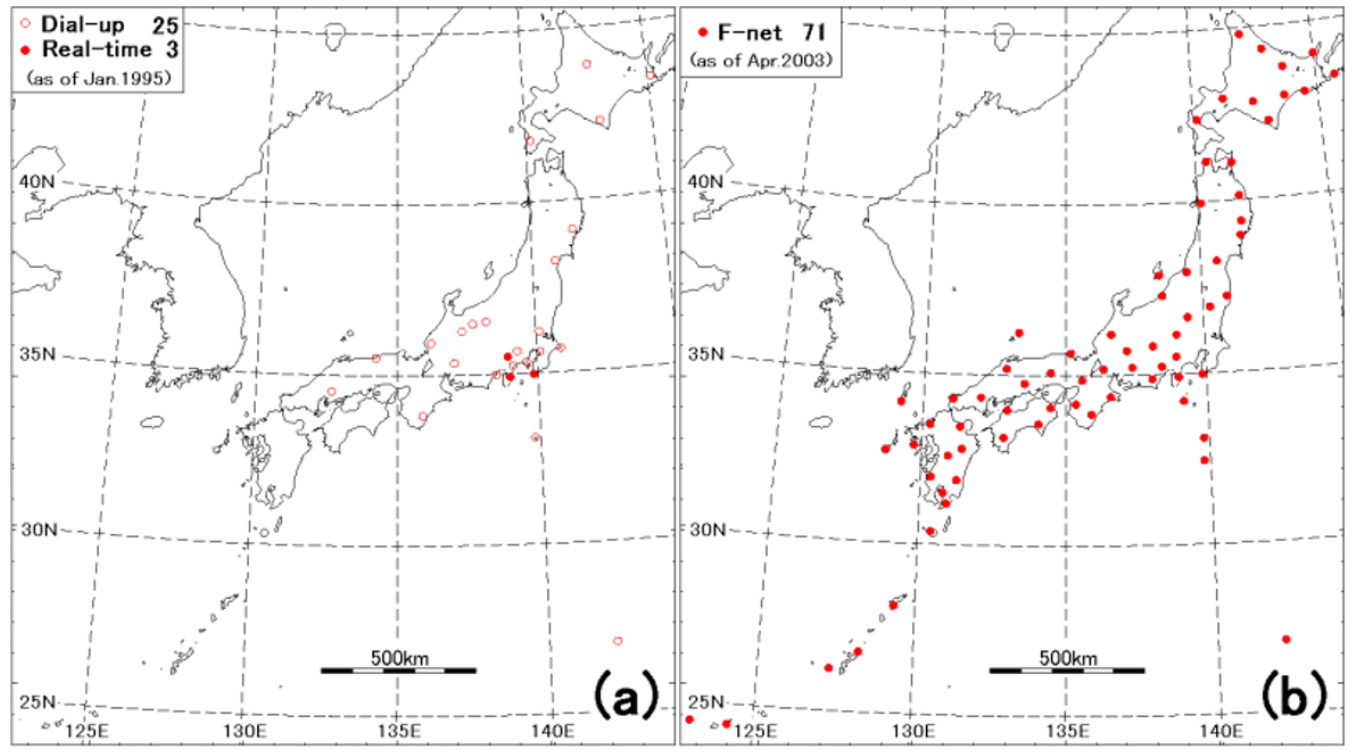

Fig. 2. Distribution of broadband seismic stations in Japan (a) at the time of 1995 Kobe earthquake and (b) newly added F-net stations as of April 2003.

tral Japan (Fig. 1(a)). Although the seismic data obtained from these networks were partly exchanged between groups, they were basically processed independently.

As to the broadband observation, UNIV and JMA operated 22 stations and 1 station respectively, while NIED had constructed 5 stations for the FREESIA (Fundamental Research on Earthquakes and Earth's Interior Anomaly) project. Out of these 28 stations, only three were operated on a real-time basis at the time of 1995 Kobe earthquake, while the others were operated on a dial-up system (Fig. 2(a)). Until the start of construction of F-net in 1997, the FREESIA network was further extended to 20 stations covering Japan Island, among which 11 stations were operated on a real-time basis.

On the other hand, the nation-wide digital observation network for strong motion was operated by JMA with 258 stations (60 stations with JMA87-type seismograph and 198 stations with JMA93-type seismograph) covering the whole of Japan with an average spacing of $60 \mathrm{~km}$ (Fig. 3(a)). The other local strong-motion networks were also operated by various organizations according to their own purposes.

\subsection{After Kobe earthquake}

Within a year of Kobe earthquake, NIED has completed a strong-motion network consisting of 1000 stations covering Japan, whose number was increased to 1034 as of April 2003 (Fig. 3(b)). The network is called K-NET (Kyoshin network Japan; Kinoshita, 1998), where Kyoshin is a Japanese word to mean strong-motion. On the other hand, seismic intensity observation network in Japan for public service was also drastically strengthened after Kobe earthquake. JMA completely switched to use 'instrumental seismic intensity' in April 1996 to speed up the acquisition of intensity data as 


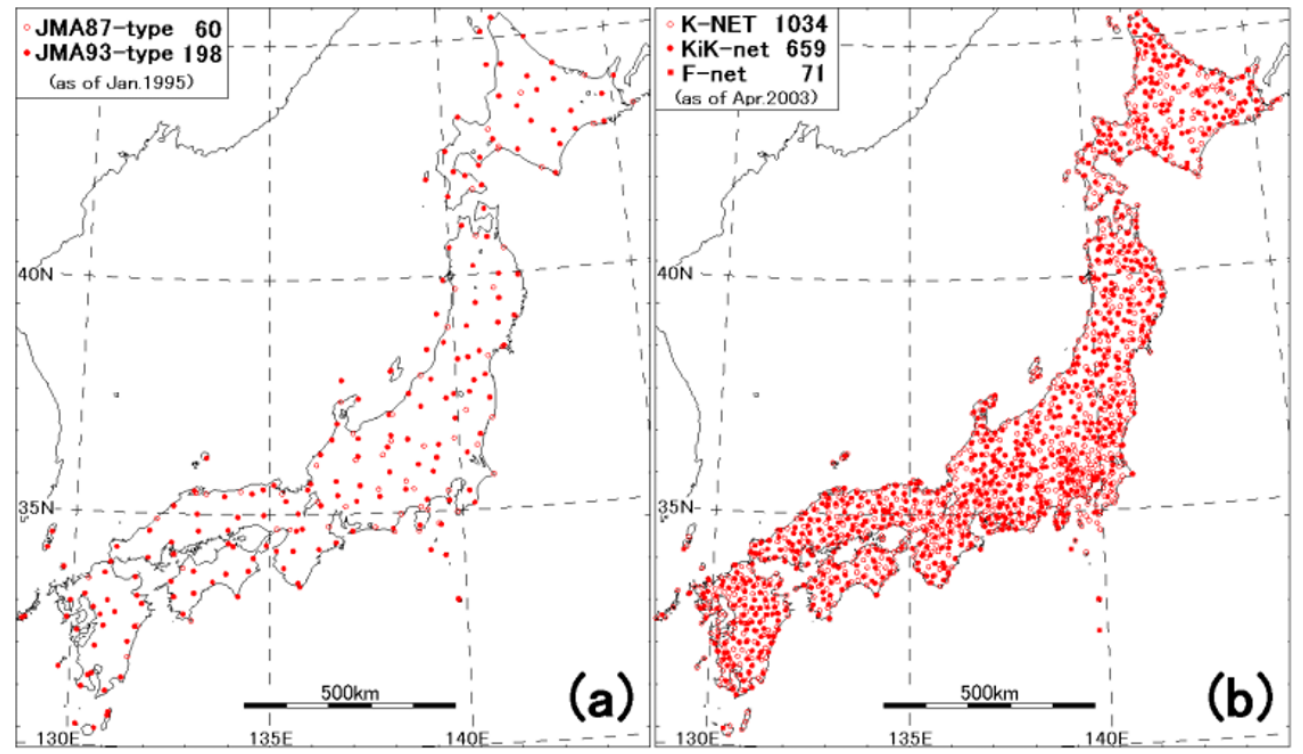

Fig. 3. Distribution of strong motion seismic stations in Japan (a) at the time of 1995 Kobe earthquake and (b) newly added K-NET, KiK-net and F-net stations as of April 2003.
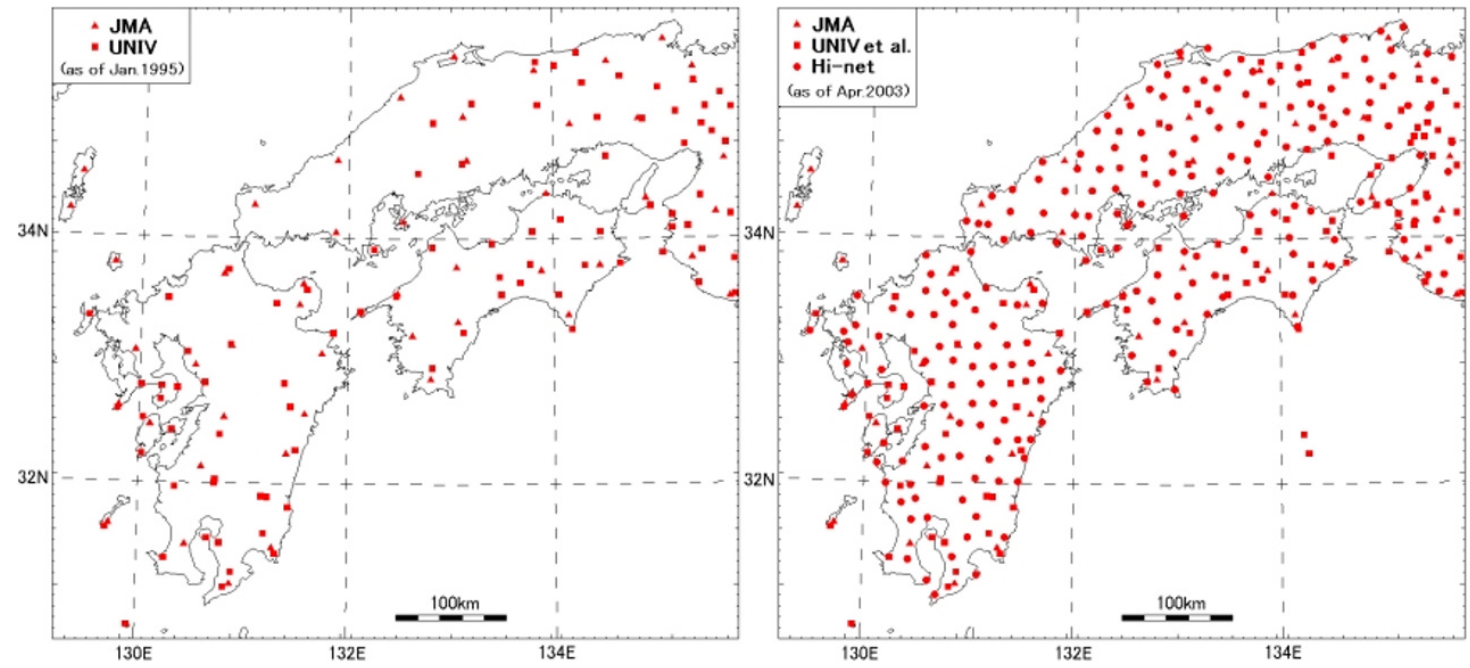

Fig. 4. Comparison of the distributions of high sensitivity seismic stations in western Japan before (left) and after (right) the Kobe earthquake of 1995 .

well as to increase the density of reporting sites. In contrast to 150 sites (basically local offices of JMA) to report seismic intensities before Kobe earthquake, JMA is now operating 600 intensity-meters covering Japan and also collecting the data from 2800 intensity-meters operated by local governments.

In parallel to the construction of the new strong motion network, the KIBAN project was started to drastically improve upon the existing Japanese seismic observation system. A large number of high-sensitivity, broadband, and strong motion seismographs were quickly installed to fill in large gaps in network coverage and to realize a unified network covering the whole of Japan. The construction of the new seismic networks was also accomplished by NIED. As of April 2003, cumulative number of the newly constructed borehole-type high sensitivity seismic stations reached to 696 (Fig. 1(b)) and the new network is called Hi-net (High sensitivity seismograph network Japan). The improvement in the station density was especially remarkable in western Japan (Fig. 4). At most of the Hi-net stations, a pair of strong-motion seismographs was also equipped both at depth and at ground surface. This network of 659 uphole/downhole pair of strong-motion seismograph (Fig. 3(b)) is separately called KiK-net (KIBAN Kyoshin network Japan). KiK-net is a word synthesized from KIBAN project and K-NET.

On the other hand, the total number of the newly constructed stations and the already existed vault-type broadband seismic stations reached to 71 as of April 2003 (Fig. 2(b)) and the new network is called F-net (Full-range seismograph network Japan). At the F-net station three component velocity type strong motion seismographs were also installed in the same vault as had been done at the FREESIA stations (Fig. 3(b)).

All the high-sensitivity data including Hi-net and preexisting networks of JMA, UNIV, and NIED were telemetered to JMA. Unified data processing to monitor the seismic 


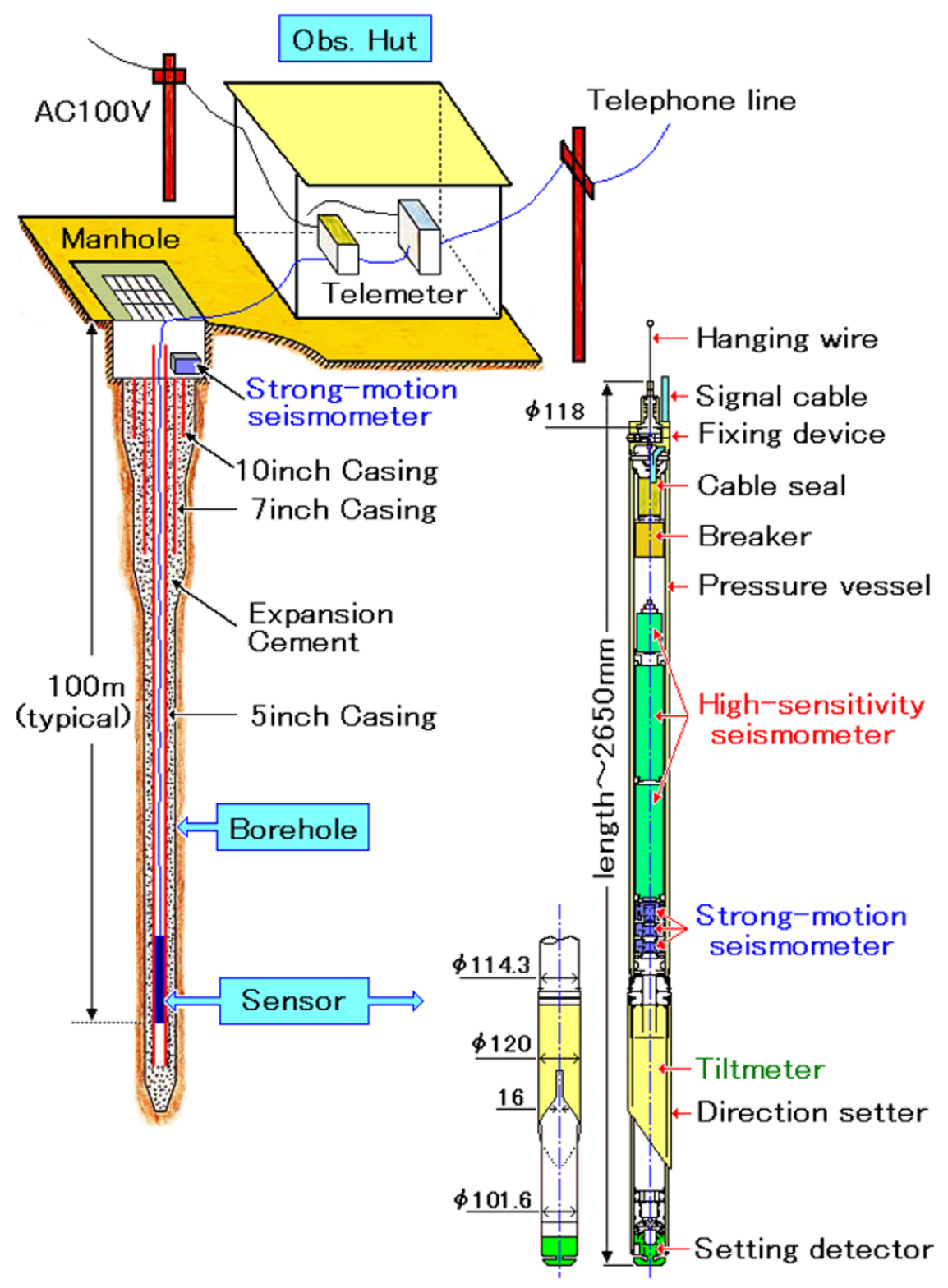

Fig. 5. Configuration of the Hi-net/KiK-net station.

activity in and around Japan was started by JMA on October 1997. The same telemetry signals were also shared to university group in real time using a communication satellite on June 2002. At the same time all the data as well as those from F-net, K-NET, and KiK-net were quickly collected by NIED for archive of data and distribution to the public. In the following sections, the details of these networks are introduced in turn.

\section{High Sensitivity Seismograph Networks in Japan}

When the HERP set up the KIBAN project, the policy to construct high sensitivity seismograph network was as follows. The magnitude of earthquake is determined from the fault size and the dislocation amount. If the deeper limit of the inland seismicity will be precisely clarified at a specified area, we can empirically estimate the maximum size of earthquake at the area using a scaling law, even if it is dif- ficult to estimate fault length and dislocation amount. Since the depth limit of the seismogenic zone of inland earthquakes is usually $15-20 \mathrm{~km}$ in Japan, it was requested to construct a seismic network with a spacing of $15-20 \mathrm{~km}$ to assure precise focal depth determination of the earthquakes at such a depth. The KIBAN project recommended a uniform network of high sensitivity seismographs covering the whole of Japan utilizing the existing high sensitivity seismic stations of JMA, UNIV, and NIED, as much as possible. It also recommended to install the seismograph in a borehole to avoid surface ground noise, to obtain physical properties such as $\mathrm{P}$ and $\mathrm{S}$-wave velocities along the borehole, and to co-locate a strong motion seismograph to supplement the scale out of the high sensitivity seismograph.

As to the network of borehole seismic stations, NIED had already accumulated experiences for Tokyo metropolitan deep borehole array (Takahashi, 1982) and the Kanto-Tokai seismic network (Hamada et al., 1985). Based on these ex- 
Table 1. Number of boreholes with different depths at the Hi-net stations as of April 2003.

\begin{tabular}{cr}
\hline Borehole depth range & Number \\
\hline depth $=0 \mathrm{~m}$ & 19 \\
depth $<100 \mathrm{~m}$ & 5 \\
$100 \mathrm{~m} \leqq$ depth $<110 \mathrm{~m}$ & 333 \\
$110 \mathrm{~m} \leqq$ depth $<200 \mathrm{~m}$ & 123 \\
$200 \mathrm{~m} \leqq$ depth $<210 \mathrm{~m}$ & 110 \\
$210 \mathrm{~m} \leqq$ depth $<300 \mathrm{~m}$ & 37 \\
$300 \mathrm{~m} \leqq$ depth $<500 \mathrm{~m}$ & 33 \\
$500 \mathrm{~m} \leqq$ depth $<1000 \mathrm{~m}$ & 12 \\
$1000 \mathrm{~m} \leqq$ depth $<2000 \mathrm{~m}$ & 14 \\
$2000 \mathrm{~m} \leqq$ depth & 10 \\
\hline \multicolumn{2}{c}{ total } \\
\end{tabular}

periences, NIED was charged with the construction of the new seismic network, Hi-net (High sensitivity seismograph network Japan). As of April 2003, the total number of high sensitivity seismic stations in Japan including Hi-net and existing ones reached to nearly 1250 . Under the condition that Hi-net must be operated by a staff of limited size, data transmission and processing systems were designed to guarantee rational operation, easy maintenance, high reliability, and quick recovery from troubles, by adopting widely used modern technology and by extensive utilization of outsourcing services in system operation, maintenance and watching.

\subsection{Hi-net station}

To achieve stable high sensitivity seismic observation avoiding surface ground noise, seismographs are settled at the bottom of the borehole of $100 \mathrm{~m}$ depth or more at each Hi-net station (Fig. 5). Short period three component velocity seismometers $(1 \mathrm{~Hz}, 200 \mathrm{~V} / \mathrm{m} / \mathrm{s})$ are installed at the bottom of the observation well together with three component accelerometers and two component borehole tiltmeters. All instruments are manufactured by AKASHI Corporation (Obara et al., 2004). A pressure vessel of $2.65 \mathrm{~m}$ length containing these instruments is mechanically fixed in the borehole to assure possible pull up action for repair or version up of the sensors in future.

Although majority of the Hi-net stations have the boreholes of 100-200 m in depth, deep observation wells were made at some specific sites if necessary. Table 1 shows the number of boreholes with different depths and Table 2 shows the list of stations which have boreholes deeper than $1000 \mathrm{~m}$. Four deepest (2300-3500 m) borehole stations and 14 deep (1200-2000 m) borehole stations had been constructed under the two research projects of NIED, "Research on Seismic Activities in the Southern Metropolitan Area" and "Research on Crustal Activities in the Kanto-Tokai Area" by the early 1990's. Among these, 9 deep boreholes (MOKH, ATGH, HDKH, TKRH, CBAH, FUTH, ISSH, YKHH, and YROH) do not reach crystalline basement because of the deep structure of the Pre-Neogene layer in the metropolitan area (Suzuki, 1996). In Table 1, 37 stations are included which belong to the old Kanto-Tokai seismic network of
Table 2. List of the Hi-net stations which have boreholes deeper than 1000 $\mathrm{m}$ as of April 2003.

\begin{tabular}{|c|c|c|c|c|c|}
\hline Code & Name & Pref. & Lat. & Long. & Borehole \\
\hline HMMH & Hamamatsu & Shizuoka & $34.6650 \mathrm{~N}$ & $137.7471 \mathrm{E}$ & $1026 \mathrm{~m}$ \\
\hline ANJH & Anjou & Aichi & $34.9286 \mathrm{~N}$ & $137.0597 \mathrm{E}$ & $1085 \mathrm{~m}$ \\
\hline EDSH & Edosaki & Ibaraki & $35.9489 \mathrm{~N}$ & $140.3334 \mathrm{E}$ & $1200 \mathrm{~m}$ \\
\hline $\mathrm{NSHH}$ & Nishinohara & Yamanashi & $35.6863 \mathrm{~N}$ & $138.7371 \mathrm{E}$ & $1206 \mathrm{~m}$ \\
\hline TYOH & Taiyo & Ibaraki & $36.1156 \mathrm{~N}$ & $140.5655 \mathrm{E}$ & $1230 \mathrm{~m}$ \\
\hline TBYH & Tatebayashi & Gunma & $36.2409 \mathrm{~N}$ & $139.5476 \mathrm{E}$ & $1233 m$ \\
\hline SNDH & Sendai & Miyagi & $38.2370 \mathrm{~N}$ & $141.0003 \mathrm{E}$ & $1236 \mathrm{~m}$ \\
\hline NRTH & Narita & Chiba & $35.8275 \mathrm{~N}$ & $140.3013 E$ & $1336 \mathrm{~m}$ \\
\hline TJRH & Tajiri & Osaka & 34.3 & $135.2864 \mathrm{E}$ & $1535 \mathrm{~m}$ \\
\hline HMAH & Hashima & Gifu & $35.2736 \mathrm{~N}$ & $136.7031 E$ & $1538 m$ \\
\hline MOKH & Mooka & Tochigi & $36.4461 \mathrm{~N}$ & $139.9553 \mathrm{E}$ & $1650 \mathrm{~m}$ \\
\hline ATGH & Atsugi & Kanagawa & $35.4007 \mathrm{~N}$ & $139.3571 \mathrm{E}$ & $1800 \mathrm{~m}$ \\
\hline HDKH & Hidaka & Saitama & $35.8958 \mathrm{~N}$ & $139.3875 \mathrm{E}$ & $1800 \mathrm{~m}$ \\
\hline TKRH & Tokoroz & Saitama & $35.7996 \mathrm{~N}$ & $139.5385 E$ & $1993 m$ \\
\hline CBAH & Chiba & Chiba & $35.5425 \mathrm{~N}$ & $140.2450 \mathrm{E}$ & $2000 \mathrm{~m}$ \\
\hline FUTH & Futtsu & Chiba & $35.3412 \mathrm{~N}$ & $139.8586 \mathrm{E}$ & $2000 \mathrm{~m}$ \\
\hline ISSH & Isesaki & Gunma & $36.3111 \mathrm{~N}$ & $139.1879 \mathrm{E}$ & $2000 \mathrm{~m}$ \\
\hline YKHH & Yokohama & Kanagawa & $35.4959 \mathrm{~N}$ & $139.5227 \mathrm{E}$ & $2000 \mathrm{~m}$ \\
\hline YROH & Yoro & Chiba & $35.2834 \mathrm{~N}$ & $140.1562 E$ & $2000 \mathrm{~m}$ \\
\hline $\mathrm{KNHH}$ & Konohana & Osaka & $34.6595 \mathrm{~N}$ & $135.3924 \mathrm{E}$ & $2038 m$ \\
\hline SHMH & Shimohsa & Chiba & $35.7934 \mathrm{~N}$ & $140.0238 \mathrm{E}$ & $2330 \mathrm{~m}$ \\
\hline $\mathrm{FCHH}$ & Fuchu & Tokyo & $35.6507 \mathrm{~N}$ & $139.4736 \mathrm{E}$ & $2781 \mathrm{~m}$ \\
\hline КОTH & Koto & Tokyo & $35.6081 \mathrm{~N}$ & 139.8157E & $3000 \mathrm{~m}$ \\
\hline IWTH & Iwatsuki & Saitama & $35.9258 \mathrm{~N}$ & $139.7381 E$ & $3510 \mathrm{~m}$ \\
\hline
\end{tabular}

NIED and only telemetry systems were renewed to Hi-net compatible ones. All stations where the sensors are installed on the ground (zero depth or at a depth less than $100 \mathrm{~m}$ are come from the old Kanto-Tokai network.

\subsection{Acquisition and transmission of Hi-net data}

Seismic data at each Hi-net station are digitized with 24bit A/D converters which are placed in a pit within the observation hut to minimize the effects of temperature change. The original data with a sampling frequency of $1 \mathrm{kHz}$ or 2 $\mathrm{kHz}$ is decimated to $100 \mathrm{~Hz} 27$ bit data, compressed to the WIN-format (Urabe and Tsukada, 1992), and finally created a packet data of 1 second length to which a GPS time stamp is added (Fig. 6).

Data acquisition system of the Hi-net forms a computer network as a whole. Each station is connected to the Hinet Data Center in NIED by a frame relay (FR) network and TCP/IP protocol can be used for data transmission and network management. When the FR service is not available, the data are transmitted by modem through a conventional analog telephone line to a relay point which is connected to the FR network. All the stations are divided like a checkered pattern and are connected to either of the Sub-center A (Tokyo) or B (Kyoto) so as to prevent simultaneous data loss in wide area in case of trouble at one of the Sub-centers A and B, although they are built inside the telephone company building and are designed to be quite robust to such a trouble (Fig. 7). Using this network, we can easily control each station of the Hi-net and can monitor the status of all the equipments con- 


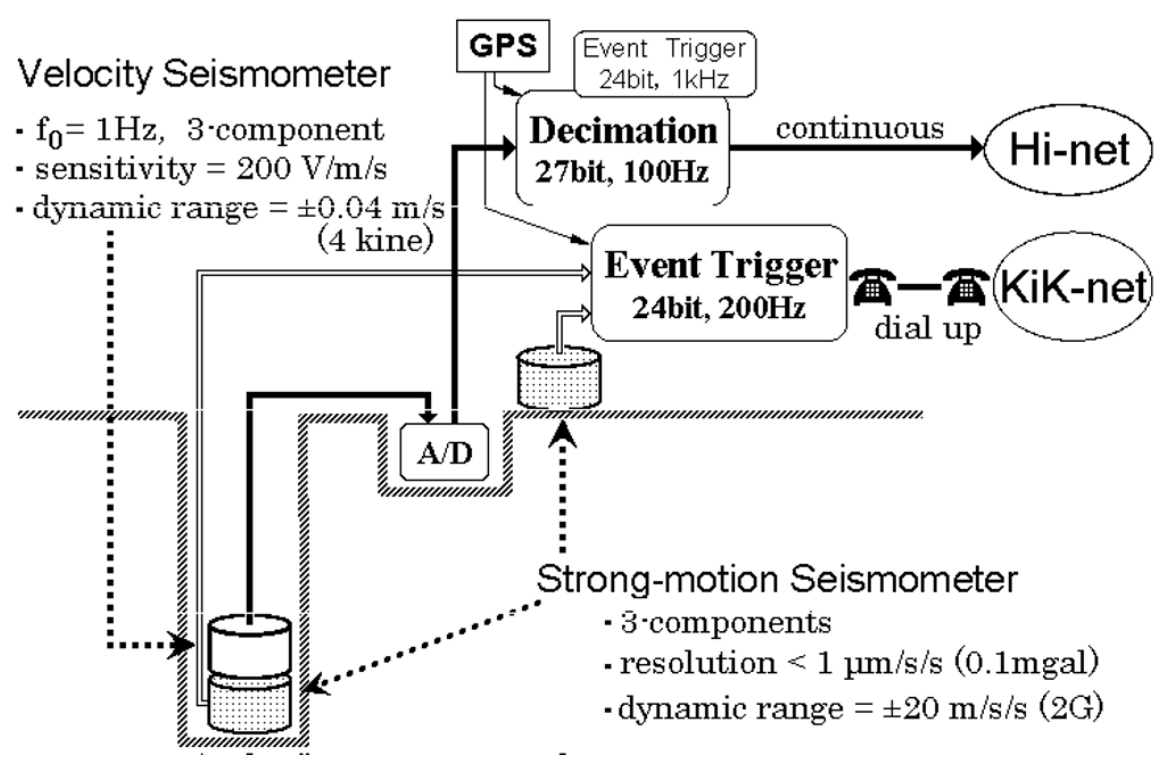

Fig. 6. Data acquisition flow chart at the Hi-net/KiK-net station.

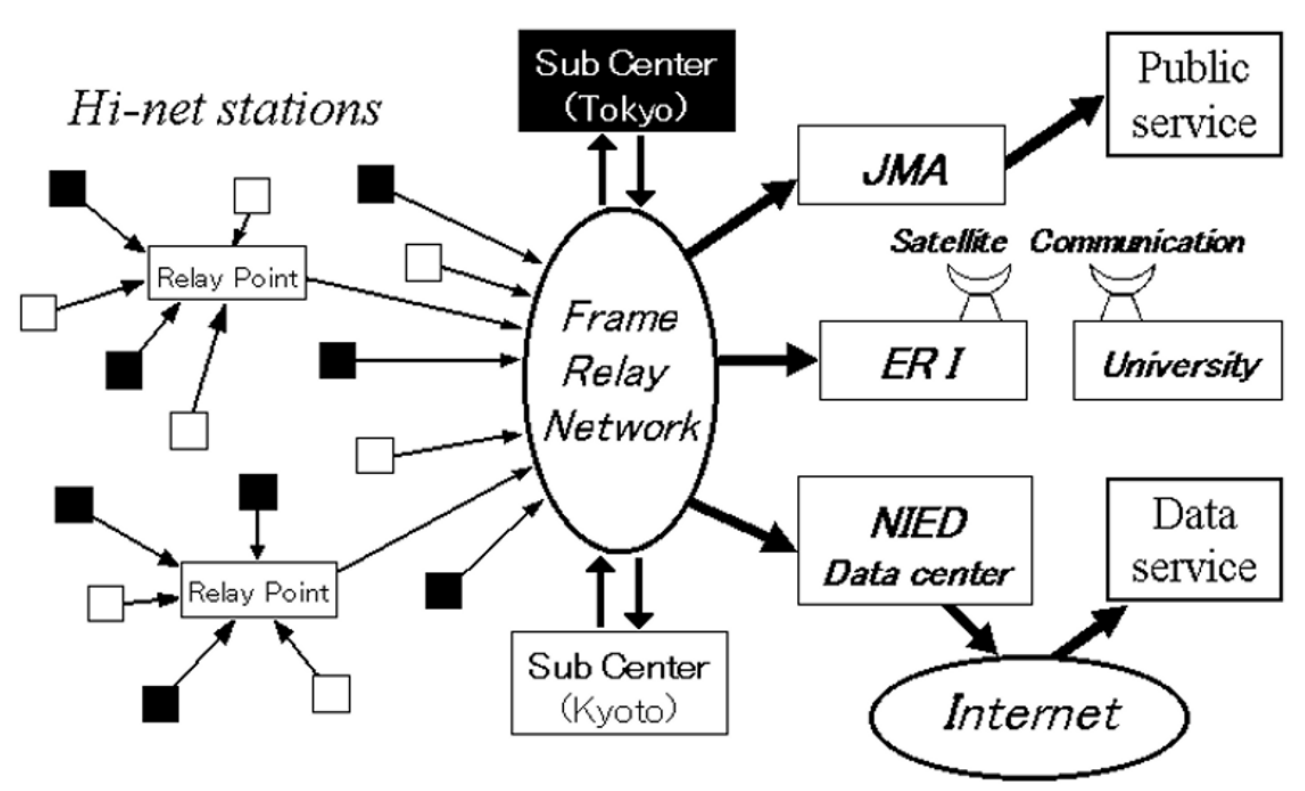

Fig. 7. Data transmission flow of the Hi-net system. Data from solid and open square stations are collected at Tokyo (black) and Kyoto (white) subcenters, respectively. Then the data are multicasted to three institutions (JMA: Japan Meteorological Agency, ERI: Earthquake Research Institute, University of Tokyo, NIED: National Research Institute for Earth Science and Disaster Prevention).

nected to the network.

Seismic signals from the pre-existing seismic networks of JMA, UNIV and NIED are also transmitted to the Subcenters $\mathrm{A}$ and $\mathrm{B}$. The whole data gathered at the Sub-centers are provided to the following three institutions. JMA receives the data to watch the seismic activity on 24 hour basis and to issue quick earthquake information for public service. Earthquake Research Institute, University of Tokyo receives the data to redistribute real time waveform data to the researchers in other universities through a satellite communication link. NIED receives the whole data for archiving and data service through the internet.

\subsection{Archive and distribution of Hi-net data}

At NIED, the data acquisition, monitoring, processing, and archive are controlled by a database management system. It automatically carries out a series of data processing such as event detection using STA/LTA (Matsumura et al., 1988), phase picking using AIC (Morita and Hamaguchi, 1984), determination of hypocenter and focal mechanism (Okada, 1988), spectral analyses and extraction of waveform parameters (Matsumura et al., 1988) like in the Kanto-Tokai system. Detection threshold of the unified network is around M1.0. The event information and triggered waveform data are archived in a disk system at the Hi-net Data Center as well as the continuous records of all the components. The disk server can store waveforms of triggered events for the 

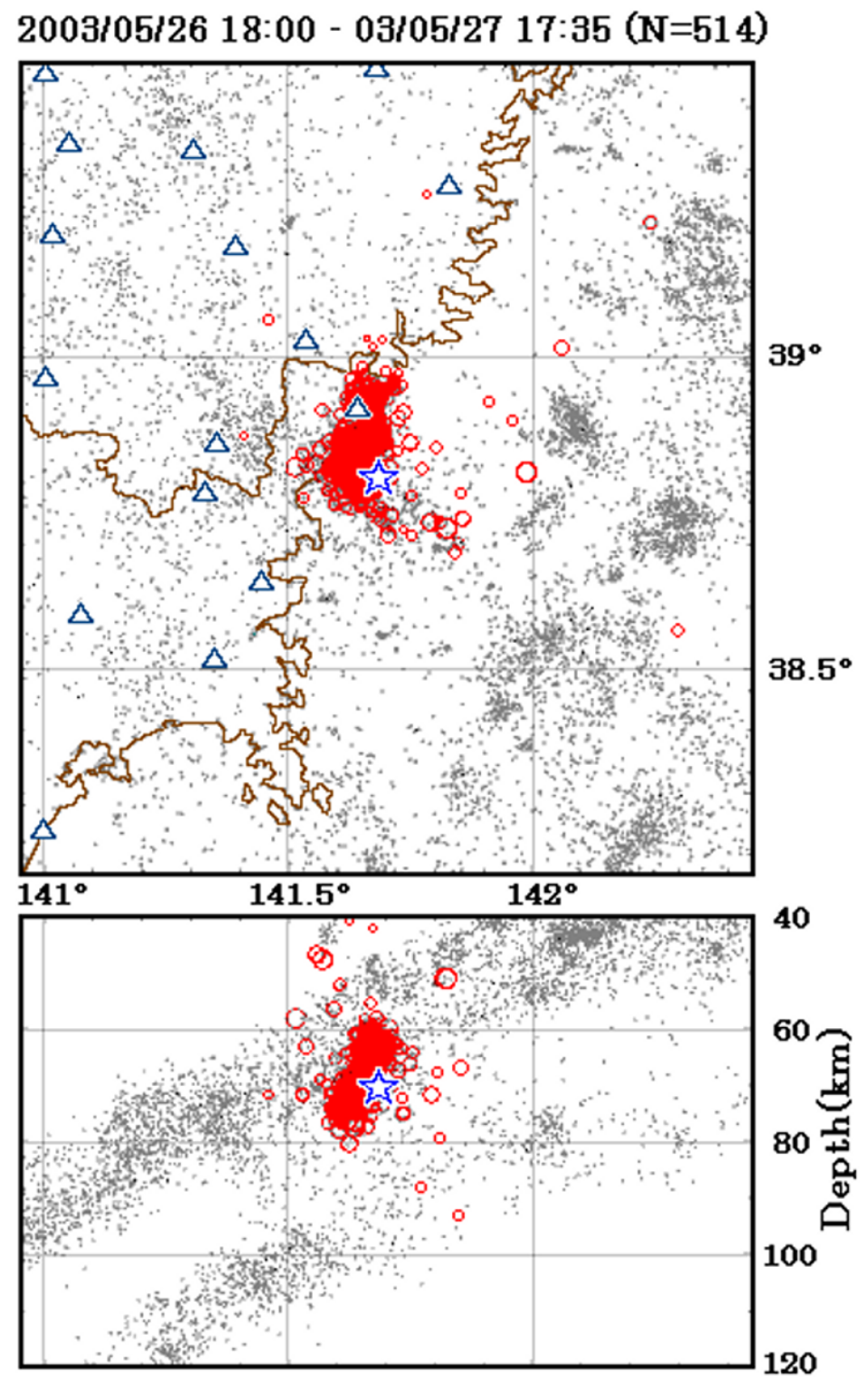

Fig. 8. The result of automatic hypocenter determination by the Hi-net system associated to the Miyagi-Oki earthquake (M7.1) of May 26, 2003. Upper is map view and the lower is EW cross section (A star: main shock, circles: aftershocks, dots: background seismicity due to JMA catalog, triangles: Hi-net stations).

most recent 5 years and continuous waveforms for the most recent 10 months. Older waveform data will be stored in a magnetic device such as DLT (Digital Linear Tape).

Under the concept that earthquake related information collected by the government are the common properties of the people, all the data obtained from the unified network including Hi-net are provided to the researchers and general public through the internet (http://www.hinet.bosai.go.jp/). Users can retrieve the parameters of final hypocenters and phase reading data determined by JMA as well as raw data of the continuous or triggered waveforms of arbitrary stations. They can also browse the results of automatic analysis of hypocenter and focal mechanism solution, the epicentral map, and the image of continuous record at arbitrarily selected stations with 1 hour length or 24 hour preview within recent 2 weeks.

As a recent example, Figure 8 shows a hypocenter distribution determined by the Hi-net system associated to the
Miyagi-Oki earthquake (M7.1) of May 26, 2003. Triangles indicate the Hi-net stations and the background seismicity data are due to the JMA catalog. Figure 9 shows an example of web screen image of continuous 1 hour record of UD component at a nearby station, RZTH (Rikuzentakada, Iwate Pref.), provided on a web page. Here is displayed the aftershock sequence of the 2003 Miyagi-Oki earthquake.

At some Hi-net stations, horizontal seismographs are not correctly oriented to NS and EW directions by various reasons (Shiomi et al., 2003). Basic information of station constants including this sensor orientation problem are also provided through the internet.

High quality data produced by the dense Hi-net are not only used for monitoring of seismic activity but are providing a plenty of seeds for interesting researches. Obara (2002) found a phenomenon of non-volcanic deep tremor associated with subduction of the Philippine Sea plate over a length of $600 \mathrm{~km}$ in southwest Japan. Shiomi et al. (2004) found 


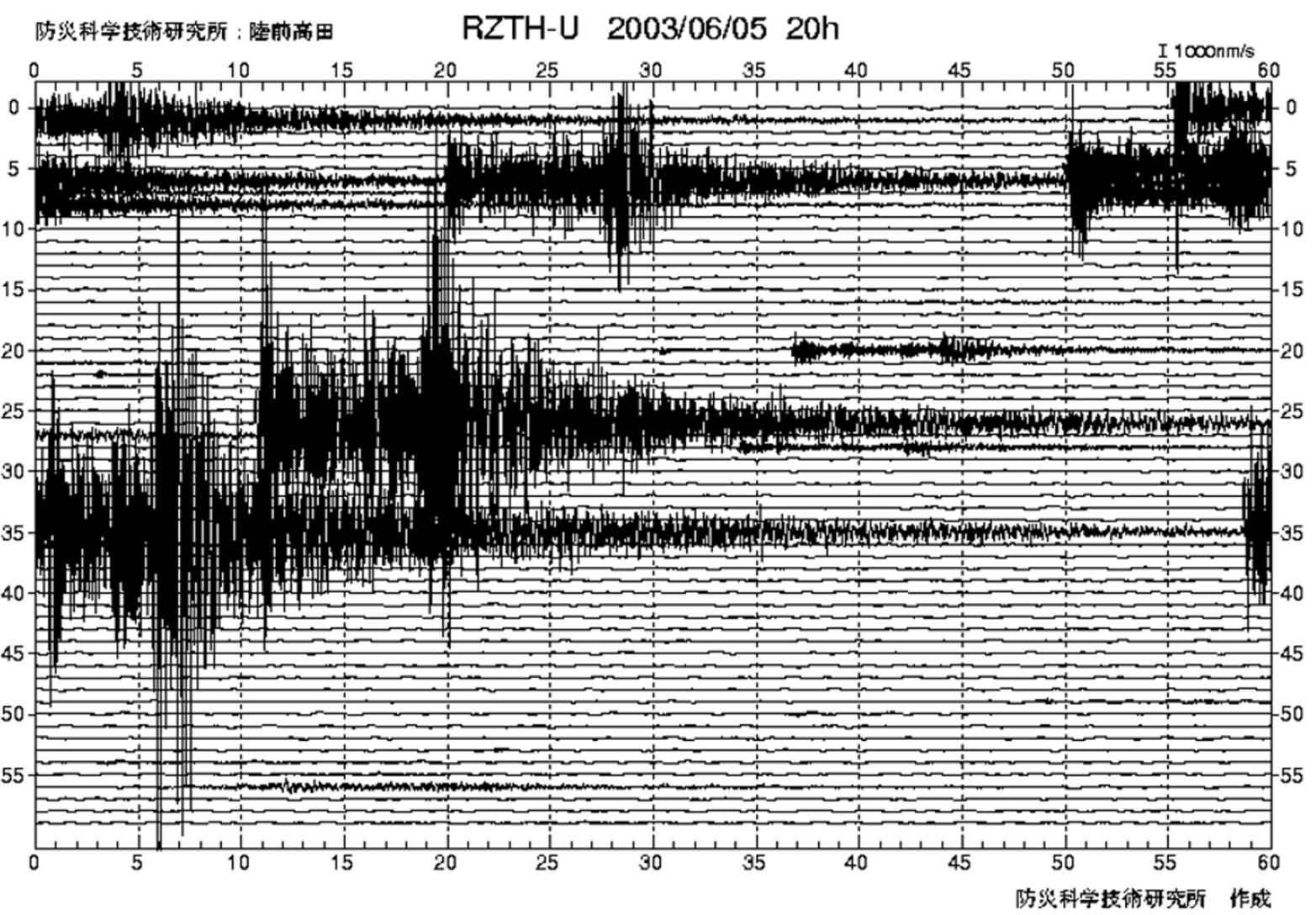

Fig. 9. An example of web screen image of continuous 1 hour record of UD-component at a Hi-net station, RZTH. It is shown the aftershock sequence of the Miyagi-Oki earthquake of May 26, 2003.

the deeper extension of the aseismic Philippine Sea slab beneath Chugoku district, western Japan, using receiver function method.

\section{Broadband Seismograph Networks in Japan}

When the HERP set up the KIBAN project, it was requested to construct a broadband seismograph network with a spacing of $100 \mathrm{~km}$ covering the whole of Japan utilizing existing broadband stations as much as possible. The KIBAN project also recommended installation of the seismograph in a vault to avoid the effect of temperature change, and to colocate a strong motion seismograph to supplement the scale out of the broadband seismograph.

These specifications were the same as FREESIA project (Fukuyama et al., 1996). Based on the experience to construct the FREESIA network, NIED was charged with the construction of the KIBAN network named F-net to which FREESIA network was merged. As of April 2003, the total number of broadband seismic stations in Japan including F-net and about 20 UNIV stations became nearly 90 .

Since the F-net must be operated by a staff of limited size, the effort was continued to assimilate the data transmission and processing systems to the Hi-net compatible ones as much as possible.

\subsection{F-net station}

As broadband seismographs are very sensitive to the change of temperature, the seismographs are installed in 30 to $50 \mathrm{~m}$ long vaults at each F-net station (Fig. 10). As a broadband sensor, STS-1 (Wielandt and Streckeisen, 1982) was adopted at initial 22 stations. Later, since the manufacturing of the STS-1 was stopped, STS-2 seismometer was installed at the remaining stations instead. In the vault, three component velocity type strong motion seismograph, VSE311 or VSE355G2 manufactured by Tokyo Sokushin Co., Ltd., is also installed to extend the dynamic range of the observation.

\subsection{Acquisition and transmission of F-net data}

In the beginning, a data logger, Q680 of Quanterra Company was equipped at the F-net stations following the FREESIA network. The seismic data were digitized with 24-bit A/D converters with a sampling frequency of $80 \mathrm{~Hz}$ and a GPS time stamp was added. These data were directly transmitted to NIED with a $64 \mathrm{Kbps}$ dedicated telephone line using TCP/IP protocol.

Later, to assure rational and efficient operation, the old systems have been replaced with the Hi-net compatible ones. At present, all the stations are sharing the same data acquisition and transmission system as the Hi-net using 27 bit, 100 $\mathrm{Hz}$ format.

\subsection{Archive and distribution of F-net data}

At NIED, the data acquisition, monitoring, processing and archive are controlled by the database management system. It automatically carries out a series of data processing including determination of moment tensor solutions. The moment tensor analysis is also made by operators to improve the quality of the results as had been done in the FREESIA system (Fukuyama et al., 1998). Waveform data obtained from the F-net stations are archived in the same manner as 


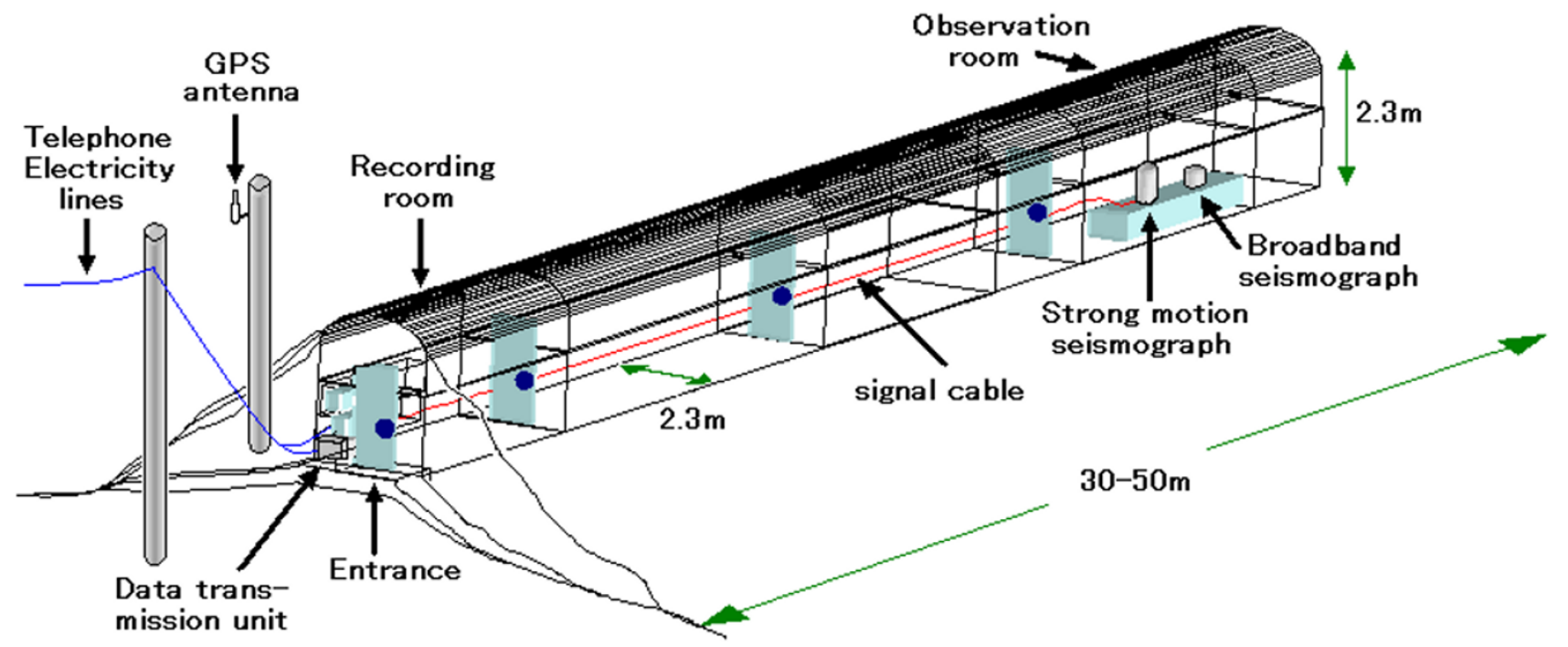

Fig. 10. Configuration of the F-net station.

the Hi-net data. In addition, waveform data down-sampled to $20 \mathrm{~Hz}$ and $1 \mathrm{~Hz}$ are also stored in a disk server for the most recent 5 years. Older waveform data will be stored in a magnetic device such as DLT. All the data obtained from the F-net are provided to the researchers and general public through the internet (http://www.fnet.bosai.go.jp/). Users can retrieve raw data of the continuous waveforms of arbitrary stations and can browse the results of moment tensor analysis. They can also browse the map of moment tensor distribution and the image of continuous record (1 day or 1 hour length) of arbitrary components at arbitrarily selected stations.

As a recent example of web screen image, Figure 11 shows a moment tensor distribution in the Tohoku district determined by the F-net system in the 10 month period prior to the occurrence of the 2003 Miyagi-Oki earthquake (M7.1). Figure 12 shows an example of continuous half a day record of UD component at a station, FUK (Fukue, Nagasaki Pref.), which is associated to the 2003 Miyagi-Oki earthquake.

High quality data produced by the dense F-net are providing a lot of interesting research results. Fukuyama et al. (2001) analyzed stress fields due to 2000 eruption of the Usu volcano and swarm activity associated to 2000 eruption of Miyakejima volcano. Kumagai et al. (2001) developed a caldera formation model associated to the volcanic activity of Miyakejima in 2000. Kubo et al. (2002) analyzed maximum horizontal stress directions in and around Japan and local stress field in the focal zone of the western Tottori earthquake of 2000 (M7.3).

\section{Strong-motion Seismograph Networks in Japan}

Just after the 1995 Kobe earthquake, NIED decided to construct a nation-wide network of strong motion seismograph, K-NET, as an original project of NIED. It was planned to set up 1000 stations covering the whole of Japan with a spacing of $25 \mathrm{~km}$ and to immediately provide obtained data with a completely open policy.

Later, when the HERP set up the KIBAN project, it was

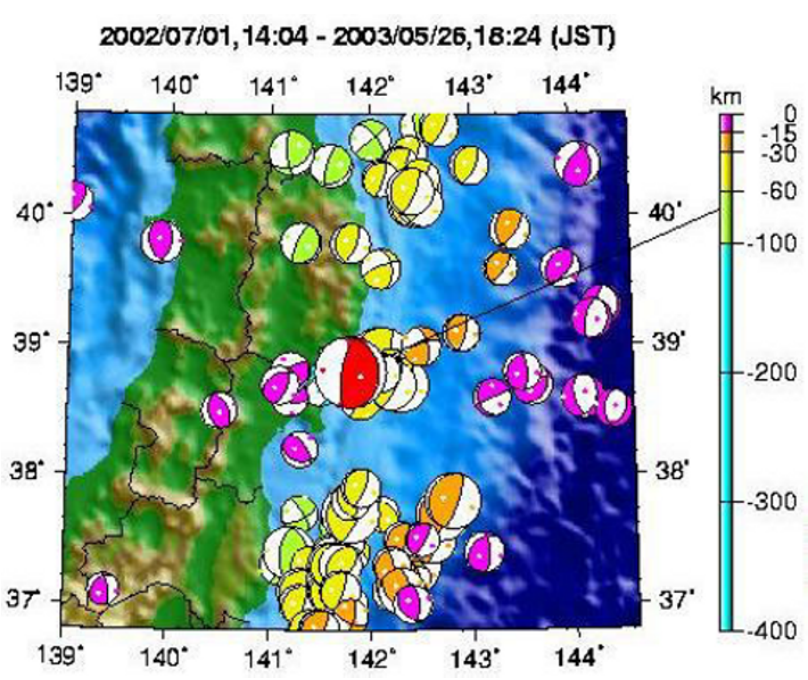

Fig. 11. An example of web screen image of moment tensor distribution in the Tohoku district determined by the F-net. Data in the 10 month period prior to the Miyagi-Oki earthquake of May 26, 2003 are displayed.

recommended that strong motion seismograph should be colocated with high sensitivity seismograph when the Hi-net station will be constructed. NIED installed an acceleration type strong motion seismograph at the bottom of the borehole together with a high sensitivity seismograph at newly constructed Hi-net stations. At that time, it was also planned to install a strong motion seismograph of the same type on the ground surface just above the borehole. The network of the uphole/downhole pair of strong-motion seismographs is named KiK-net.

Since K-NET was planned to record strong motion at typical inhabitant area, the station usually locates at soil site, whereas KiK-net station is located at rock site if available, because it is co-located to the Hi-net aimed for microearthquake observation. 


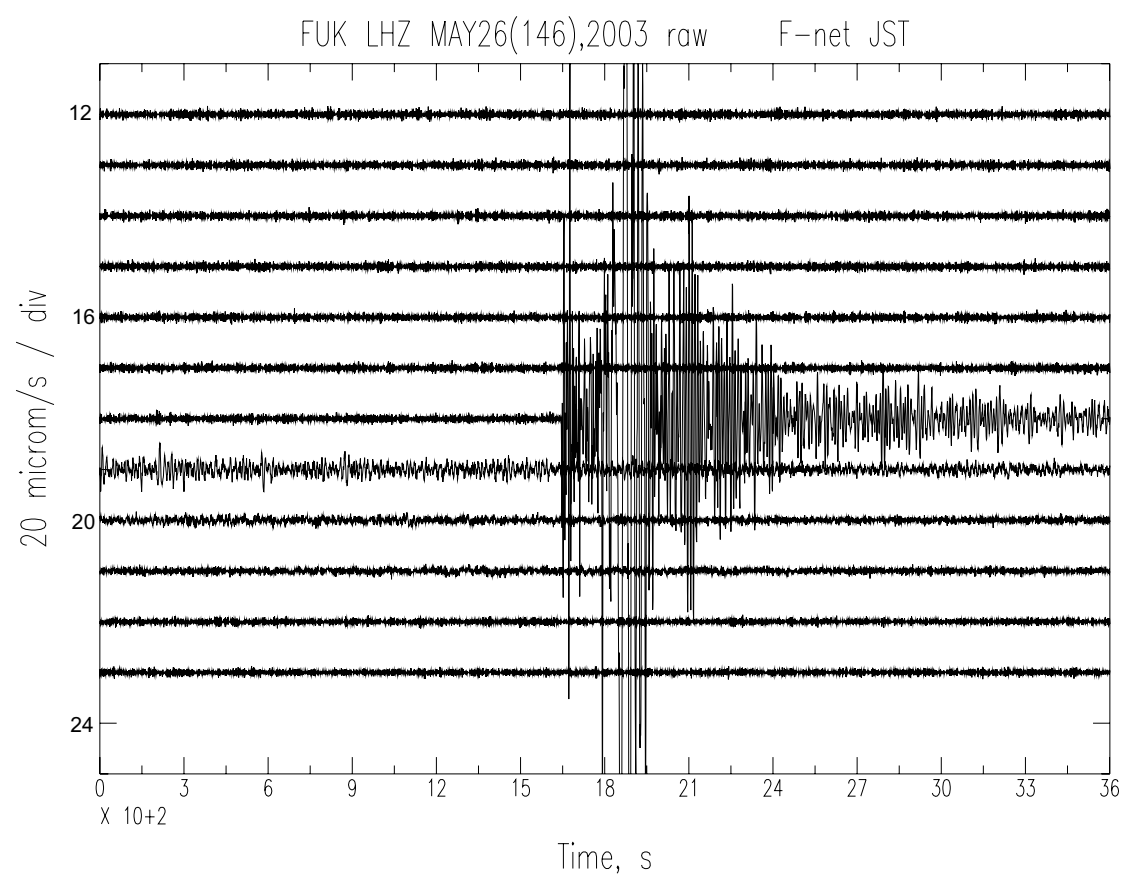

Fig. 12. An example of continuous half a day record of UD component at a F-net station, FUK. The broadband waveforms are shown associated to the Miyagi-Oki earthquake (M7.1) of May 26, 2003.

\subsection{K-NET station}

At each K-NET station, an observation system called KNET95 is installed at the ground surface covered by a FRP (Fiber Reinforced Plastics) hut as shown in Fig. 13 (Kinoshita, 1998). K-NET95 was manufactured by AKASHI Corporation and consists of three component acceleration type strong motion seismograph and a data logger having a 24 bit A/D converter with a sampling frequency of $100 \mathrm{~Hz}$ and $8 \mathrm{MB}$ memory which can record waveforms of 2.5 hours in total. Resolution of the acceleration is less than 1 micro $\mathrm{m} / \mathrm{s} / \mathrm{s}(0.1 \mathrm{mgal})$ and the maximum measurable acceleration is $\pm 20 \mathrm{~m} / \mathrm{s} / \mathrm{s}$ (2000 gals). Internal clock of the recording system ( 1 ppm precision) is calibrated by a GPS signal every hour in the accuracy of $5 \mathrm{msec}$.

K-NET95 was replaced by K-NET02 at 443 K-NET stations in 2003 (Kunugi et al., 2004). The K-NET02 is manufactured by OYO Corporation and Hakusan Corporation with improved specification of the maximum measurable acceleration of $\pm 40 \mathrm{~m} / \mathrm{s} / \mathrm{s}$ (4000 gals) with a dynamic range of 135 $\mathrm{dB}$ or more, and the maximum sampling frequency of 200 $\mathrm{Hz}$ with a $512 \mathrm{MB}$ memory. Each K-NET station has its account code, which is used as its station code.

\subsection{KiK-net station}

At most of the Hi-net stations, strong motion seismographs are installed both on the ground surface and at the bottom of the observation well (Fig. 5) forming the KiK-net (Aoi et al., 2000). It should be noted that each Hi-net station has two codes, conventional one and an account code. Usually Hi-net station is called by its conventional code, while the identical KiK-net station is called by its account code.

Instrumentation of the KiK-net is basically the same as that of the K-NET95. The difference is a sampling frequency of $200 \mathrm{~Hz}$ and $85 \mathrm{MB}$ memory which can hold 6 component waveforms of 6.5 hours in total. Event trigger of the data recorder is controlled by the signal of the downhole sensor. Typically, event recording is started with a threshold level of $2-4 \mathrm{~mm} / \mathrm{s} / \mathrm{s}(0.2-0.4$ gals $)$ and ended with 30 seconds continuation of the level below $1 \mathrm{~mm} / \mathrm{s} / \mathrm{s}$ (0.1 gals), keeping minimum recording length of 120 seconds.

\subsection{Acquisition and transmission of K-NET and KiK- net data}

Strong motion data of the K-NET and KiK-net are collected through dial up operations by the Data Center of NIED. When an earthquake which registered JMA intensity 3 or more occurs, JMA issues a quick report of source parameters through a JMA satellite. Upon receiving the quick report, the Data Center automatically estimates the spatial distribution of maximum acceleration using an empirical attenuation law by Fukushima and Tanaka (1990) and starts to retrieve the strong-motion records for the corresponding stations using 25 telephone lines (Fig. 6).

Dial up operation often encounters delays caused by jamming of communication line and the data collection may be considerably delayed especially in case of large earthquakes. To resolve this problem, the construction of a new data acquisition system based on dial out operation is currently in progress. In the new system, triggered waveforms will be independently sent to the Data Center using 500 telephone lines when the ground motion exceeds a certain threshold level. The new system was first introduced at $420 \mathrm{~K}-\mathrm{NET}$ stations in the west Japan and 23 stations in the northeast Japan in 2003.

\subsection{Archive and distribution of K-NET and KiK-net data}

At NIED, the collected waveform records of all the K-NET and KiK-net stations are stored in a disk system at the Data Center and all the data are provided to the researchers and general public through the internet 


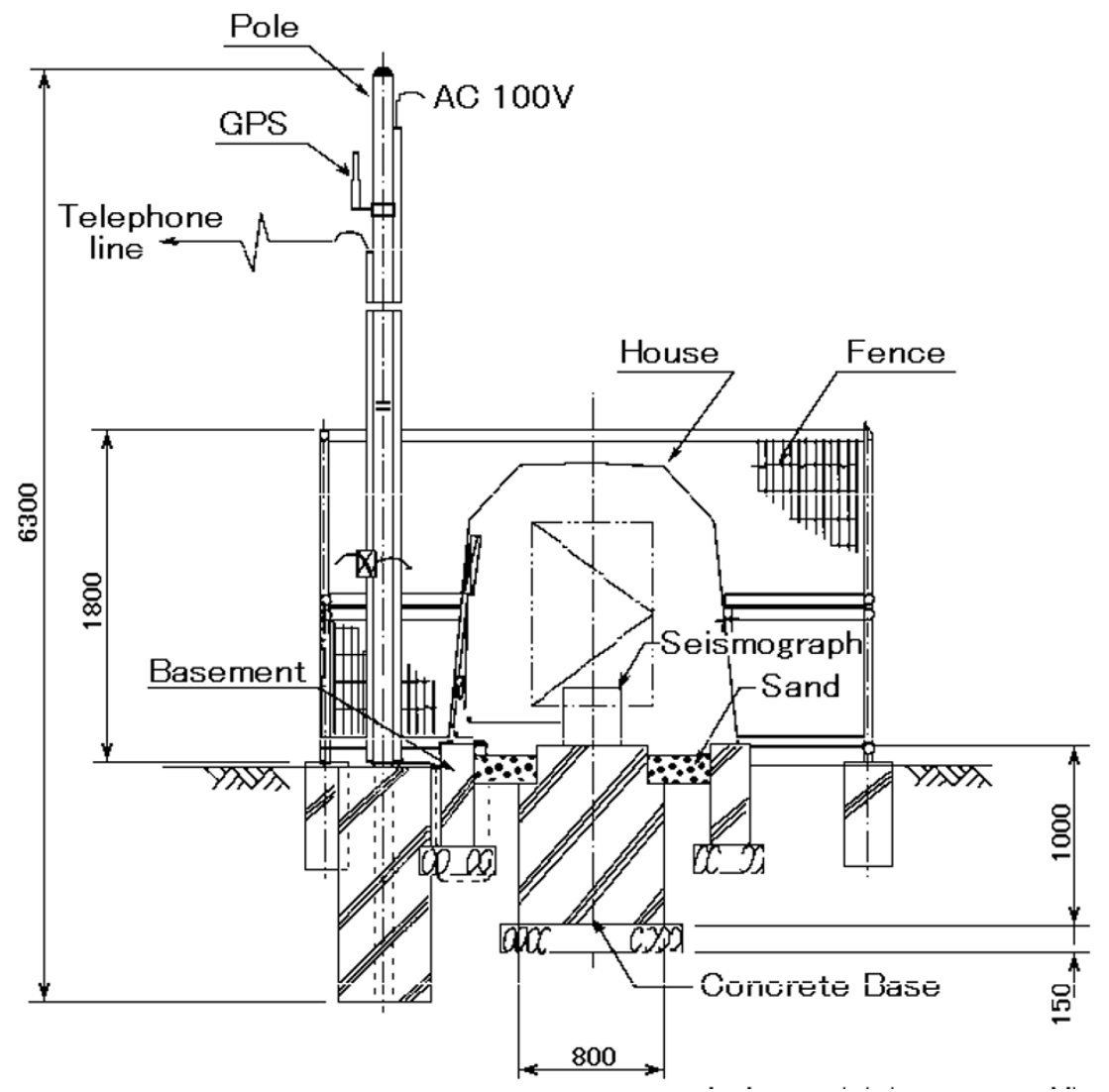

Fig. 13. Configuration of the K-NET station (Kinoshita, 1998).

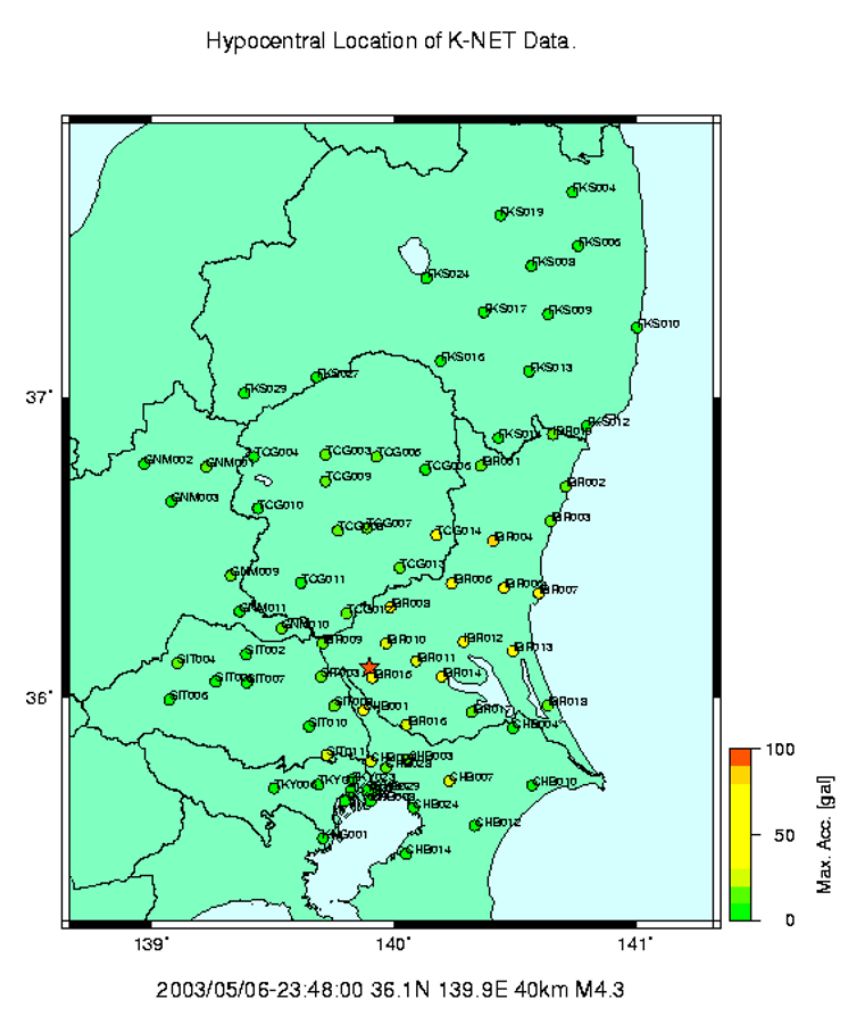

KereINIED

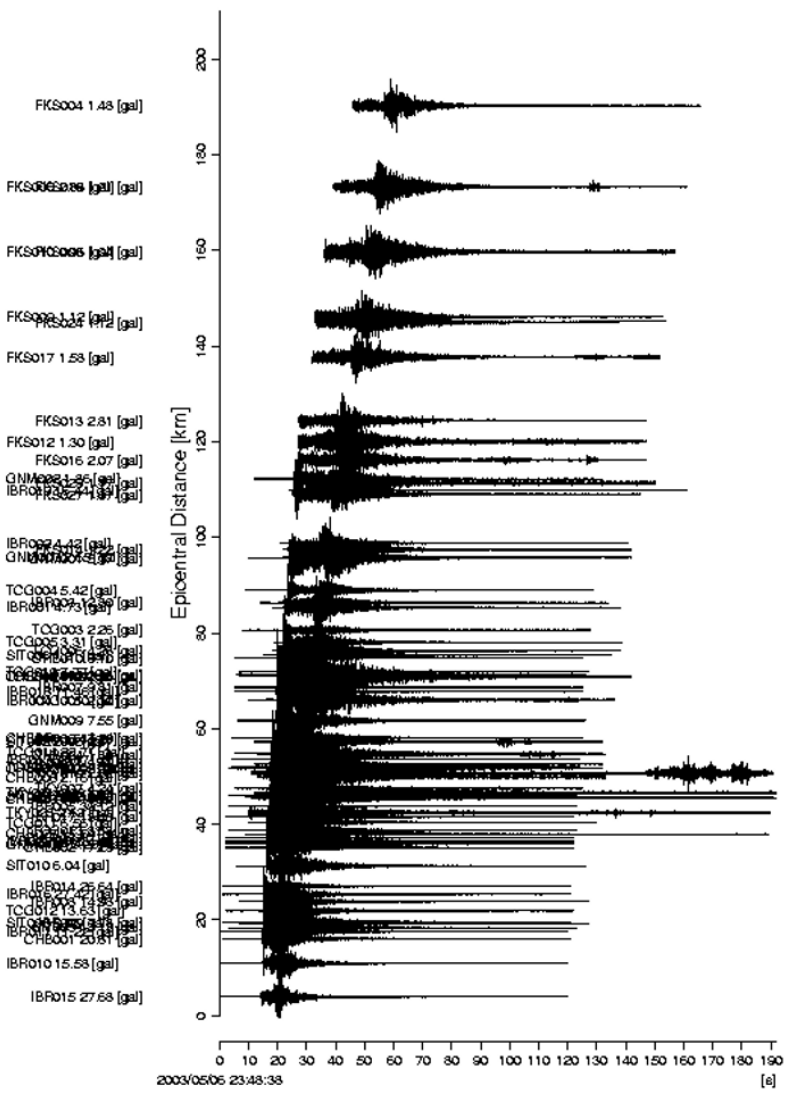

Fig. 14. An example of web screen image of the acceleration map and the paste up of strong motion records associated to a moderate earthquake in southwestern Ibaraki Pref. 1 gal corresponds to $1 \mathrm{~m} / \mathrm{s} / \mathrm{s}$. 

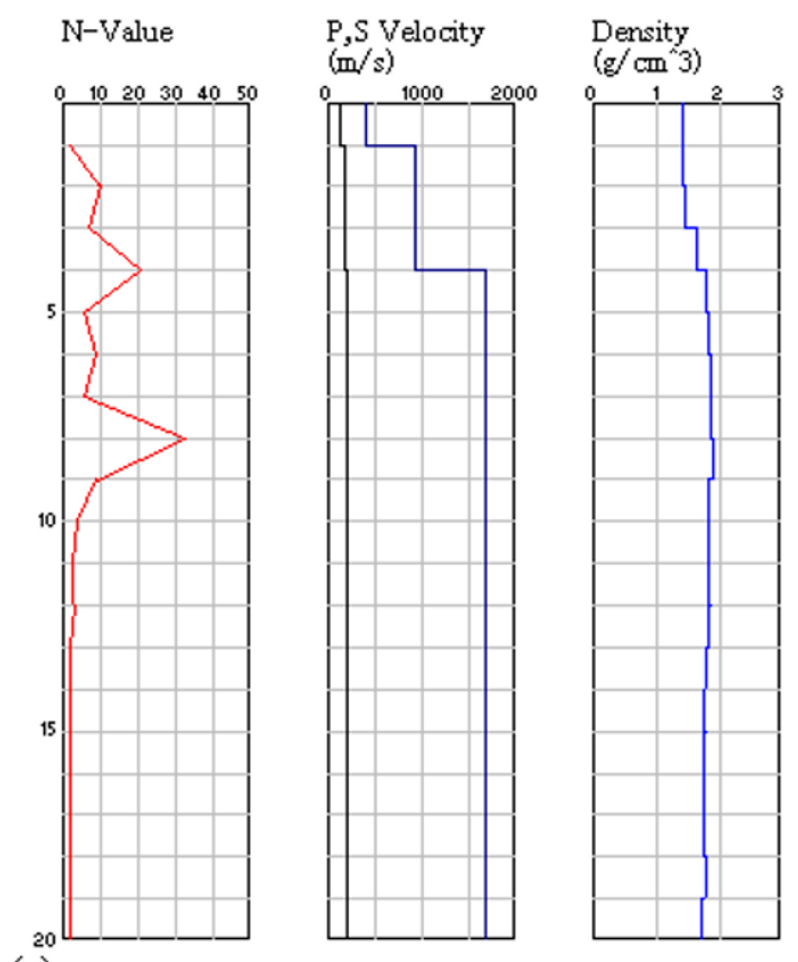

Soil Column
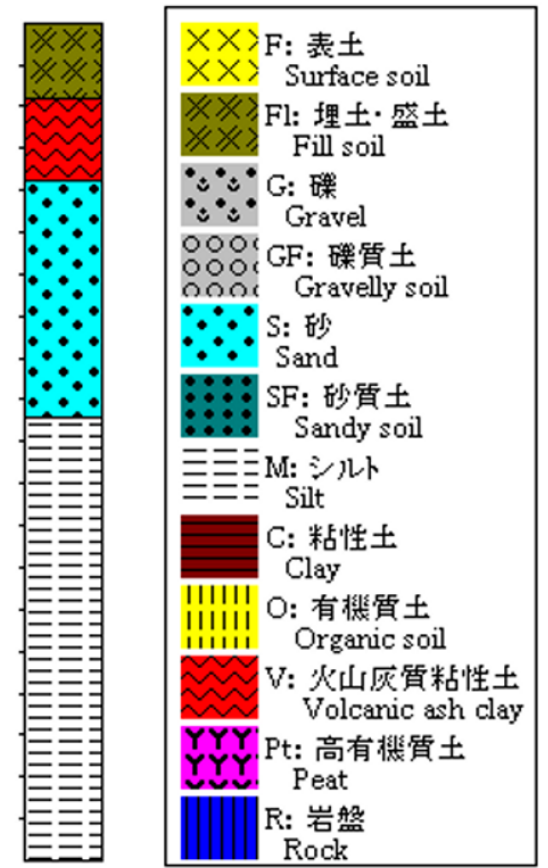

Fig. 15. An example of web screen image of the soil condition at a specific K-NET site. $1 \mathrm{~g} / \mathrm{cm}^{3}$ corresponds to $1,000 \mathrm{~kg} / \mathrm{m}^{3}$.

2000/10/06-13:30

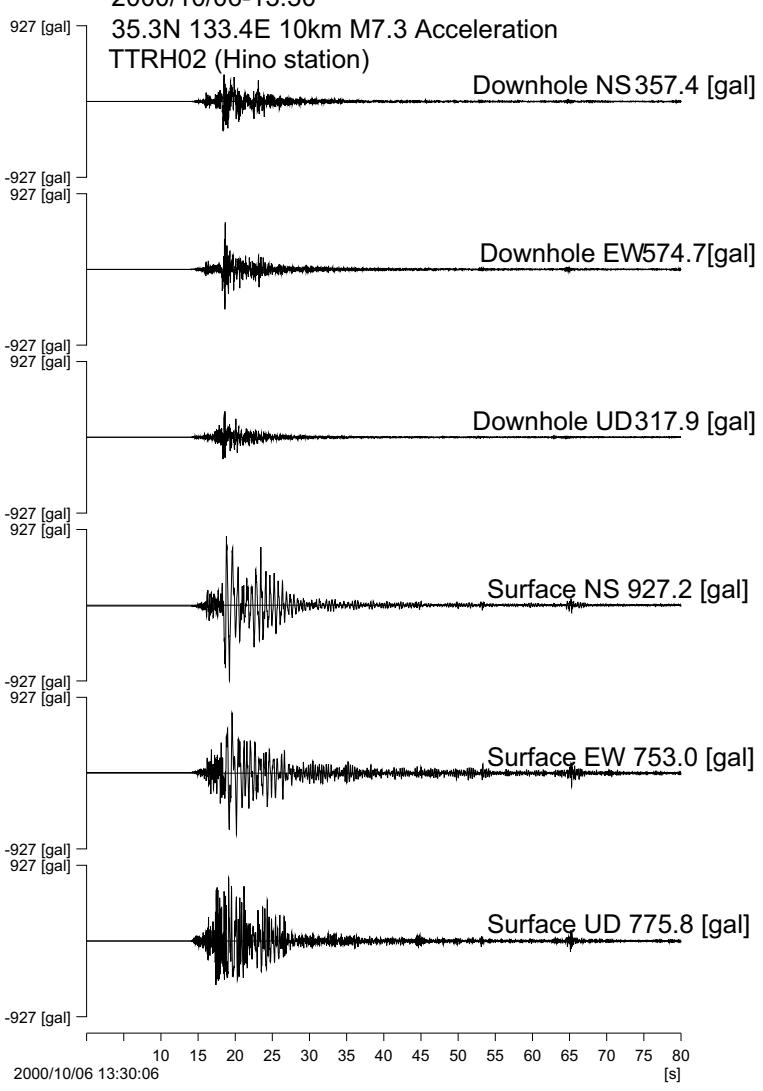

Fig. 16. An example of records obtained by an uphole/downhole pair of strong motion seismograph at a KiK-net station, TTRH02 (Hino; epicentral distance $8 \mathrm{~km}$ ). It is shown the waveform associated to the western Tottori earthquake (M7.3) of October 6, 2000. 1 gal corresponds to 1 $\mathrm{m} / \mathrm{s} / \mathrm{s}$. (http://www.k-net.bosai.go.jp/, http://www.kik.bosai.go.jp/). Users can select specific events or stations with a combination of key parameters to download the raw data. They can also browse, select, and retrieve various information such as distribution map of acceleration, paste up of waveforms, station map, site information including soil condition and logging data, and so on. Figure 14 shows an example of web screen image of the acceleration map and the paste up of the strong motion records associated to the moderate earthquake of M4.3 occurred in the southwestern Ibaraki Prefecture. Figure 15 is another example of web screen image showing the soil condition at a specific K-NET site.

Six component records obtained from the uphole/downhole pair of strong motion seismographs at each KiK-net station enable us to quantitatively evaluate the site effect at the station. For example, associated to the occurrence of the western Tottori earthquake (M7.3) of October 6, 2000, the nearest station, TTRH02 (Hino; epicentral distance $8 \mathrm{~km}$ ), recorded peak amplitude of 9.27 $\mathrm{m} / \mathrm{s} / \mathrm{s}$ (927 gals) in NS-component on the ground surface but it was $5.75 \mathrm{~m} / \mathrm{s} / \mathrm{s}$ (575 gals) in EW-component at the bottom of $100 \mathrm{~m}$ borehole (Fig. 16). Figure 17 shows the distribution of peak accelerations around the source region, where (a) is the one on the ground surface, and (b) is the one at 100-200 $\mathrm{m}$ depth. Epicentral distribution in the period, 13:30-23:59, October 6, is also plotted over (a). Compared to the simple elliptic pattern in (b), the surface pattern showed in (a) is rather complex reflecting the variety of soil conditions and amplification factors at each site.

High quality data produced by the dense K-NET and KiKnet are providing a plenty of seeds for interesting researches. For example, in the special issue of Earth, Planets and Space 

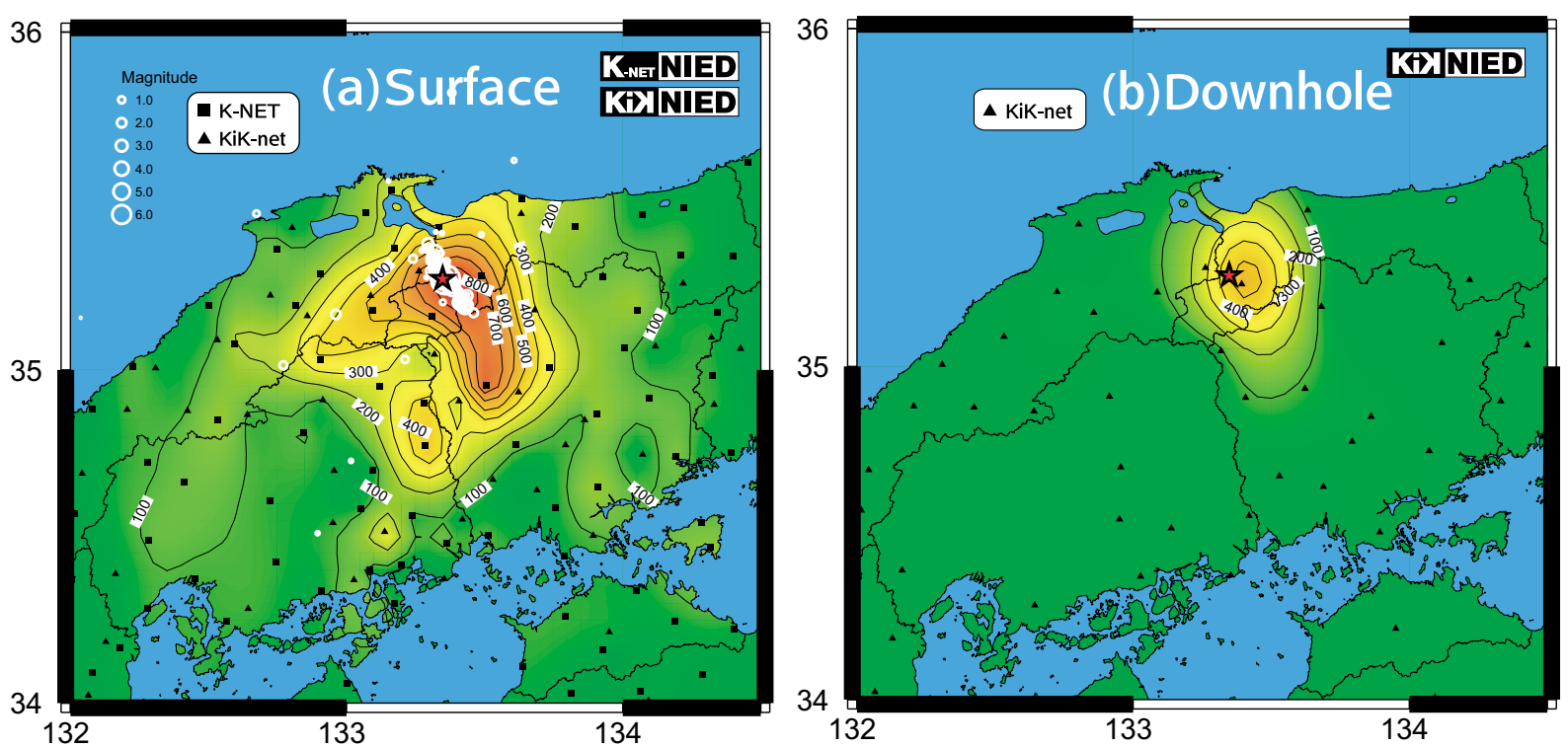

Fig. 17. Distribution of the peak accelerations associated to the western Tottori earthquake of October 6,2000 (a) on the ground surface and (b) at 100-200 $\mathrm{m}$ depth. Epicentral distribution in the period, 13:30-23:59, October 6, is also plotted over (a). 1 gal corresponds to $1 \mathrm{~m} / \mathrm{s} / \mathrm{s}$.

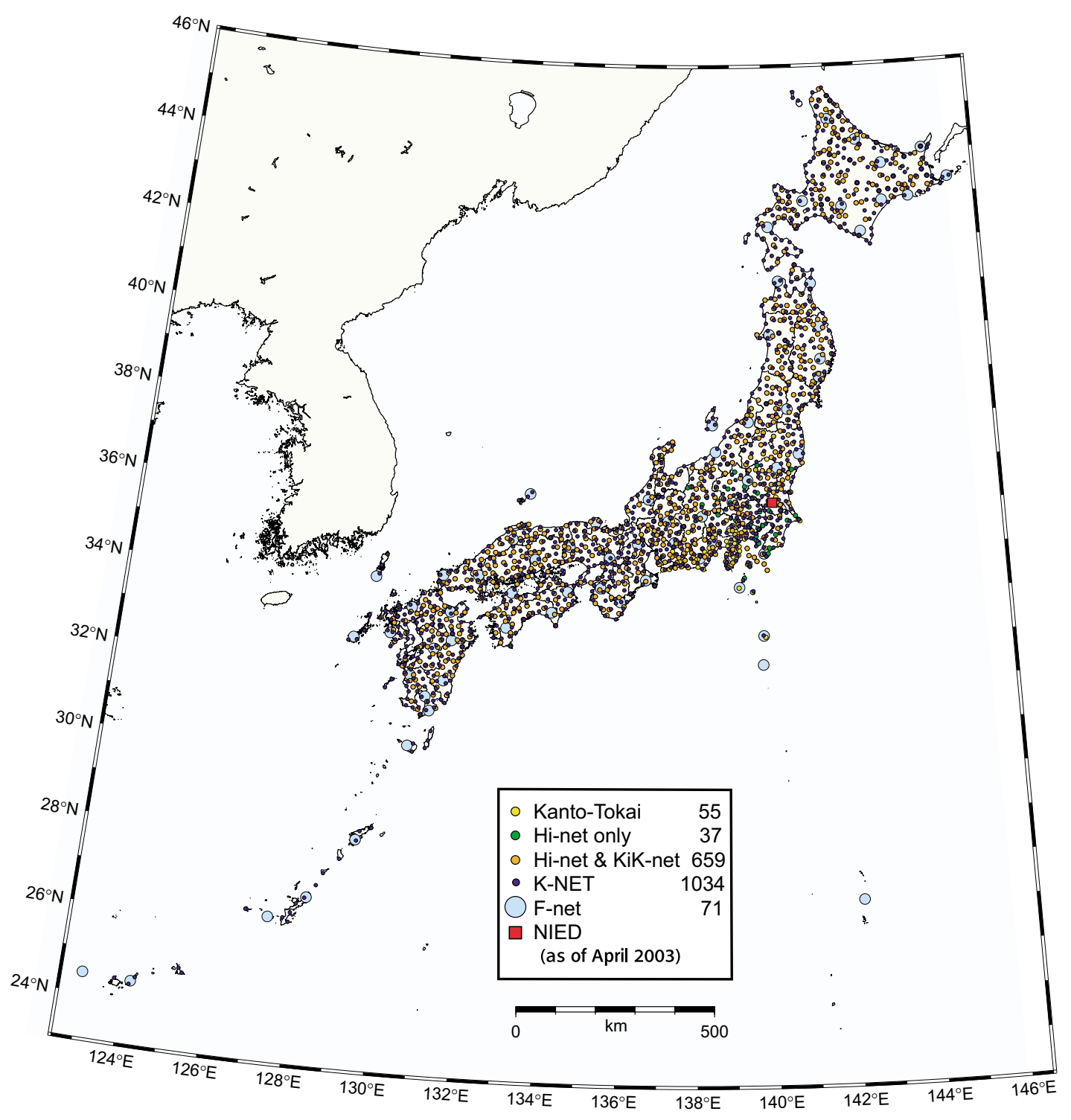

Fig. 18. Distribution of seismic stations operated by NIED as of April 2003. 
for the 2003 Tokachi-oki earthquake, five papers are using $\mathrm{K}-\mathrm{NET}$ and KiK-net data to discuss the source process or local site effects in the source region (Yagi, 2004; Honda et al., 2004; Kamae and Kawabe, 2004; Koketsu et al., 2004; Yamanaka et al., 2004).

\section{Summary}

Following the KIBAN project by the HERP, NIED constructed several kinds of extensive modern seismic networks covering the whole of Japan, Hi-net, F-net, K-NET, and KiKnet. Figure 18 shows the distribution of seismic stations which are operated by NIED as of April 2003. The total number of the stations which are operated by NIED amounts to 1856 . In this figure, 55 stations belonging to the old Kanto-Tokai network and 37 'Hi-net only' stations are included. At the latter stations, only the telemetry systems of the Kanto-Tokai network were renewed to the Hi-net compatible ones but are not equipped with an uphole/downhole pair of strong motion seismographs like the KiK-net.

All the high-sensitivity data including the Hi-net and preexisting seismic networks operated by various institutions are transmitted to and processed by JMA to monitor seismic activity in and around Japan. At the same time, the data are shared to university group for a variety of research works and to NIED for data archive and distribution under the fully open policy. All the data obtained by these networks are now open to any use through world-wide web (http://www.bosai.go.jp/).

Acknowledgments. The construction and the maintenance of the Hi-net, F-net, K-NET, and KiK-net are supported by all the staffs in the National Disasters Information Center and the Solid Earth Research Group, NIED as well as the helps from a number of related companies. Regarding to the seismic networks before Kobe earthquake, we got the informations from Drs. N. Hamada, N. Nishide and Y. Ishigaki of Japan Meteorological Agency, Dr. S. Watada of Earthquake Research Institute, University of Tokyo, and Dr. R. Matsu'ura of Association for the Development of Earthquake Prediction. We wish to thank them for all the cooperation. The comments from Dr. W. Ellsworth of U.S. Geological Survey and the other anonymous reviewers as well as those from a guest editor, Dr. E. Fukuyama of NIED, were quite helpful to clarify this paper.

\section{References}

Aoi, S., K. Obara, S. Hori, K. Kasahara, and Y. Okada, New Japanese uphole/downhole strong-motion observation network: KiK-net, Seism. Res. Lett., 72, 239, 2000.

Fukushima, Y. and T. Tanaka, A new attenuation relation for peak horizontal acceleration of strong earthquake ground motion in Japan, Bull. Seism. Soc. Am., 80, 757-783, 1990.

Fukuyama, E., M. Ishida, S. Hori, S. Sekiguchi, and S. Watada, Broadband seismic observation conducted under the FREESIA project, Rep. Natl. Res. Inst. Earth Sci. Disas. Prev., 57, 23-31, 1996 (in Japanese with English abstract).

Fukuyama, E., M. Ishida, D. S. Dreger, and H. Kawai, Automated seismic moment tensor determination by using on-line broadband seismic waveforms, Zisin (J. Seism. Soc. Japan), 51, 149-156, 1998 (in Japanese with English abstract).

Fukuyama, E., A. Kubo, H. Kawai, and K. Nomura, Seismic remote monitoring of stress field, Earth Planets Space, 53, 1021-1026, 2001

Hamada, K., M. Ohtake, Y. Okada, S. Matsumura, and H. Sato, A high quality digital network for microearthquake and ground tilt observations in the Kanto-Tokai area, Japan, Earthq. Pred. Res., 3, 447-469, 1985.

Hatanaka, Y., T. Iizuka, M. Sawada, A. Yamagiwa, Y. Kikuta, J. M. Johnson, and C. Rocken, Improvement of the analysis strategy of GEONET, Bull. Geograph. Surv. Inst., 49, 11-37, 2003.

Honda, R., S. Aoi, N. Morikawa, H. Sekiguchi, T. Kunugi, and H. Fujiwara, Ground motion and rupture process of the 2003 Tokachi-oki earthquake obtained from strong motion data of K-NET and KiK-net, Earth Planets Space, 56, 317-322, 2004.

Kamae, K. and H. Kawabe, Source model composed of asperities for the 2003 Tokachi-oki, Japan, earthquake $\left(\mathrm{M}_{\mathrm{JMA}}=8.0\right)$ estimated by the empirical Green's function method, Earth Planets Space, 56, 323-327, 2004

Kinoshita, S., Kyoshin-net (K-NET), Seism. Res. Lett., 69, 309-332, 1998.

Koketsu, K., K. Hikima, S, Miyazaki, and S. Ide, Joint inversion of strong motion and geodetic data for the source process of the 2003 Tokachi-oki, Hokkaido, earthquake, Earth Planets Space, 56, 329-334, 2004.

Kubo, A., E. Fukuyama, H. Kawai, and K. Nomura, NIED seismic moment tensor catalogue for regional earthquakes around Japan: quality test and application, Tectonophysics, 356, 23-48, 2002.

Kumagai, H., T. Ohminato, M. Nakano, M. Ooi, A. Kubo, H. Inoue, and J. Oikawa, Very-long-period seismic signals and caldera formation at Miyake Island, Japan, Science, 293, 687-690, 2001.

Kunugi, T., H. Fujiwara, S. Adachi, S. Aoi, and K. Kasahara, The new strong-motion seismograph of the K-NET, Abstracts 2004 Japan Earth Planet. Sci. Joint Meeting, S046-020, 2004.

Matsumura, S., Y. Okada, and S. Hori, Procedures for seismic data processing by the Analyzing system for Precursors of Earthquake (APE), Rep. Natl. Res. Cent. Disas. Prev., 41, 45-64 (in Japanese with English abstract), 1988.

Morita, Y. and H. Hamaguchi, Automatic detection of onset time of seismic waves and its confidence interval using the autoregressive model fitting, Zisin (J. Seism. Soc. Japan), 37, 281-293 (in Japanese with English abstract), 1984.

Obara, K., Non-volcanic deep tremor associated with subduction in southwest Japan, Science, 296, 1679-1681, 2002.

Obara, K., K. Kasahara, S. Hori, and Y. Okada, A densely distributed highsensitivity seismograph network; NIED Hi-net, Japan, Rev. Scientific Instruments, 2004 (submitted).

Okada, Y., Improvement of routine programs for hypocenter determination and mechanism calculation, Rep. Natl. Res. Cent. Disas. Prev., 41, 153162, 1988 (in Japanese with English abstract).

Sagiya, T., A decade of GEONET: 1994-2003-The continuous GPS observation in Japan and its impact on earthquake studies, Earth Planets Space, 56, this issue, xxix-xli, 2004.

Shiomi, K., K. Obara, S. Aoi, and K. Kasahara, Estimation on the azimuth of the Hi-net and KiK-net borehole seismometers, Zisin (J. Seism. Soc. Japan), 56, 99-110, 2003 (in Japanese).

Shiomi, K., H. Sato, K. Obara, and M. Ohtake, Configuration of subducting Philippine Sea plate beneath southwest Japan revealed from receiver function analysis based on the multivariate autoregressive model, J. Geophys. Res., 109, B04308, doi:10.1029/2003JB002774, 2004.

Suzuki, H., Geology of the Koto deep borehole observatory and geological structure beneath the Metropolitan area, Japan, Rep. Natl. Res. Inst. Earth Sci. Disas. Prev., 56, 77-123, 1996 (in Japanese with English abstract).

Takahashi, H., The deep borehole observatories and their contribution for revealing the characteristics of microearthquake activity in the Kanto district, Rep. Natl. Res. Cent. Disas. Prev., 28, 1-104, 1982 (in Japanese with English abstract).

Urabe, T. and S. Tsukuda, WIN-A program on workstation for support of manual phase picking process on seismograms recorded by microearthquake observation network, Programme and Abstract, Seism. Soc. Japan, No. 2, p. 41, 1992 (in Japanese).

Wielandt, E. and G. Streckeisen, The leaf-spring seismometer: Design and performance, Bull. Seism. Soc. Am., 72, 2349-2367, 1982.

Yagi, Y., Source rupture process of the 2003 Tokachi-oki earthquake determined by joint inversion of teleseismic body wave and strong ground motion data, Earth Planets Space, 56, 311-316, 2004.

Yamanaka, H., K. Motoki, K. Etoh, M. Murayama, and N. Komaba, Observation of aftershocks of the 2003 Tokachi-oki earthquake for estimation of local site effects, Earth Planets Space, 56, 335-340, 2004.

Y. Okada (e-mail: okada@bosai.go.jp), K. Kasahara, S. Hori, K. Obara, S. Sekiguchi, H. Fujiwara, and A. Yamamoto 